\title{
Antifungal activity of plant extracts against Fusarium oxysporum isolated from spoilage ginger
}

\author{
Kyung Min Park ${ }^{1,2}$, KyungHyung $\mathrm{Ku}^{2}$, Minseon Koo ${ }^{1,2 *}$ \\ ${ }^{1}$ University of Science and Technology, Daejeon 34113, Korea \\ ${ }^{2}$ Korea Food Research Institute, Wanju 55365, Korea
}

\section{저장 생강 유래 부패 곰팡이 Fusarium oxysporum에 대한 식물 추출물의 항진균 활성}

\author{
박경민 ${ }^{1,2}$. 구경형 2 . 구민선 $1,2 *$ \\ ${ }^{1}$ 한국과학기술연합대학원대학교 식품생명공학, ${ }^{2}$ 한국식품연구원
}

\begin{abstract}
This study was aimed at evaluating the antifungal potentials of twelve plant extracts (Terminariae Fructus, Glycyrrhizae Radix, Cinnamomi Cortex, Taraxacum Platycarpum, Rubi Fructus, Caesalpiniae Lignum, Myristicae Semen, Caryophylli Flos, Sanguisorbae Radix, Alpiniae Katsumadaii Semen, Scutellariae Radix, Astragalus membranaceus) in preventing storage rot symptoms in ginger (Zingiber officinale). Samples were collected from ginger that had been stored for 120 days at $10-12{ }^{\circ} \mathrm{C}$. A total of ten fungi were isolated from stored non-spoiled and spoiled ginger and identified using internal transcribed spacer gene sequencing as Hypocrea virescentiflava, Fusarium oxysporum, Acremonium strictum, Fusarium solani, and Cadophora fastigiata. The causal fungus of storage rot was identified as $F$. oxysporum by pathogenicity test. Twelve candidate plant extracts were screened for antifungal activity against F. oxysporum isolated from spoiled ginger by using the disk diffusion method. In minimal inhibitory concentration (MICs) test, all ethanolic extracts of Cinnamomi Cortex, Taraxacum platycarpum, and Caryophylli Flos exhibited higher antifungal activity against $F$. oxysporum than other plant extracts. The MIC value of Cinnamomi Cortex and Caryophylli Flos were determined to be 10 ìg/dise. The MIC of T. platycarpum, $2.5 \mathrm{ig} / \mathrm{disc}$, was the lowest. Based on the results, it was concluded that Cinnamomi Cortex, T. platycarpum, and Caryophylli Flos have potential to serve as effective treatments to prevent storage rot of ginger.
\end{abstract}

Key words : Zingiber officinale, Fusarium oxysporum, plant extracts, antifungal activity

\section{서 론}

생강(Zingiber officinale)은 생강과(Zingiberanceae)에 속 하는 다년생 초본 식물로서 생강의 근경은 특유의 매운 맛과 향을 가지고 있어, 향신료로 사용되며 편강, 정과 등으 로 가공되거나 약용, 제과, 제빵 등으로 다양하게 사용되고

*Corresponding author. E-mail : minsk@kfri.re.kr Phone : 82-63-219-9161, Fax : 82-63-219-9254

Received 7 February 2018; Revised 5 March 2018; Accepted 6 March 2018.

Copyright (c) The Korean Society of Food Preservation. All rights reserved.
있다. 원산지는 동남아, 인도 등 아열대 지방으로, 고온 다습 한 환경에서 자생하고 $18^{\circ} \mathrm{C}$ 이상에서 발아하며, $20-30^{\circ} \mathrm{C}$ 환경에서 잘 자라는 것으로 알려져 있다(1).

국내 생강의 생산량은 32,000톤으로 충청남도 서산 지역 과 전라북도 완주지역에서 총 생산량의 $90 \%$ 이상을 차지하 고 있다(2). 생강은 농가 소득 기여도가 높은 작물이지만 진균, 세균 및 바이러스를 포함하여 12 종의 병해가 기록되 고 있으며 이중에서 가장 큰 피해를 주는 병해는 Pythium myriotylum와 Fusarium oxyforium에 의한 생강뿌리썩음병 (근경부패병, 일명 노랑병) 으로 해마다 발생하여 큰 피해를 주고 있어 생강 생산에 가장 큰 제한 요인이 되고 있다(3). 이들 병원균은 토양 서식균으로 고온 다습한 환경에서 병원 
균이 발아하여 유주자낭으로 형성하고, 이 유주자낭이 수 분의 경로를 따라 생강으로 침입한다고 보고되고 있다(4). 특히 Fusarium 속 균은 전 세계적으로 많은 종의 식물에 심각한 병을 일으키는 병원균으로, 이들 진균류에 의한 부 패병은 식물의 하위 잎이 황갈색으로 되며 식물체가 시들고 뿌리의 도관부는 흑갈색으로 변하여 심한 경우 식물이 고사 한다(5). Fusarium 속에 속하는 많은 종의 곰팡이들은 각종 식물 및 동물에 활성을 보이는 다양한 2차 대사 산물을 생산하고 이들 대사산물에는 식물에 독성을 나타내는 phytotoxin이 있으며 이와 같은 독소에 의해 괴사, 백화 현 상, 생장 억제, 시들음, 종자발아 억제 등을 일으키는 것으로 알려져 있다(6,7).

생강은 주로 10-11월에 수확하여 토굴저장을 하거나 저 온 저장을 하면서 연중 유통되는데, 적정 저장 조건은 13-1 $5^{\circ} \mathrm{C}$ 이고 상대습도는 $90-95 \%$ 이다 (8). 생강은 $10^{\circ} \mathrm{C}$ 이하의 저장시 저온 장애가 발생되고, $18^{\circ} \mathrm{C}$ 이상 저장 시 곰팡이의 번식과 표면 건조 및 연화등 저장 온도에 매우 민감하기 때문에 장기간 저장하고 유통하는 것이 매우 어렵다 $(9,10)$. 생강 부패 현상을 억제하고 저장성을 향상시키기 위하여 MAP 포장법(11), 강제 증발 가습 시스템 이용(12), 방사선 조사(13), Wax 처리(14) 등의 다양한 방법들에 대한 연구들 이 수행되어 왔다. 그러나 생강에서 발생되는 여러 가지 부패 관련 병원균은 토양 속에서 증식하면서 수확 과정 중 발생되는 표면 상처 부위를 통해 침입하게 되고 저장 중 발병조건에 이르면 발병하게 된다. 이를 억제하기 위하 여 유기합성농약을 사용하고 있지만 지속적인 사용으로 인한 저항성 병원균의 발현, 잔류 농약의 유해성 등이 알려 지면서 소비자들의 농약 사용 작물에 대한 기피 현상을 야기하였다(15). 따라서 작물의 저장성을 연장하고 안전성 확보를 위한 천연항균제, 특히 제어가 어려운 부패 관련 곰팡이에 대한 항진균제 개발이 필요한 실정이다. 최근에 는 다양한 천연물로부터 항균, 항진균 활성 물질의 탐색과 활성 물질 규명에 대한 연구가 활발히 진행되고 있으며, 황련(16), 정향(17), 산초(18), 계피(19) 등의 식물 추출물의 항진균 활성이 보고된 바 있다. 그러나 현재까지 생강의 저장 중 시들음병, 뿌리썩음병을 일으키는 Fusarium oxysporum에 대한 천연물의 항진균 활성 평가에 대한 연구 는 미비한 실정이다.

본 연구에서는 부패한 생강으로부터 병원균을 분리 동정 한 후 항균성 또는 항진균성 효과가 보고된 식물 추출물 12 종의 식물 병원균 대한 항진균 활성 평가를 통하여 친환 경 농작물 재배, 저장상의 안전성 및 신선도 향상을 위한 기초 자료를 제공하고자 한다.

\section{재료 및 방법}

재 료

2010년 10월 충남 서산에서 수확한 생강을 온도 $12 \pm 0$. $5^{\circ} \mathrm{C}$, 습도 $95 \pm 2{ }^{\circ} \mathrm{C}$ 조건에서 4 개월 저장 후 부패하지 않은 생강과 부패가 발생한 생강 10 종 이상을 선택하여 절단한 후 골고루 혼합하여 시료로 사용하였다.

\section{진균류 분석 및 동정}

생강의 진균류 확인을 위하여 시료 $25 \mathrm{~g}$ 을 취한 뒤 225 $\mathrm{mL}$ 의 멸균된 $0.85 \%$ saline을 넣고 Stomacher® 400 circulator (Seward, Inc., London, England)로 $160 \mathrm{rpm}$ 에서 2분간 균질 화 시킨 후 $1 \mathrm{~mL}$ 씩 취하여 $9 \mathrm{~mL}$ 의 $0.85 \%$ saline에 단계별 희석하였다. 각 단계별 희석액 $100 \mu \mathrm{L}$ 를 tartaric acid를 넣어 $\mathrm{pH}$ 를 3.5로 조정한 potato dextrose agar(PDA, Merck, Darmstadt, Germany)에 접종 후 도말하였다. 플레이트는 $25^{\circ} \mathrm{C}$ 에서 5-7일간 배양한 후 발생한 집락수를 계산하고 그 평균집락수에 희석배수를 곱하여 진균수로 하였다. 진균류 의 동정은 생강으로부터 분리된 진균류 중 형태학적 차이를 보이는 우점 진균 10종을 선발하여 TS-5.8S rDNA sequencing 을 이용하는 유전학적 방법으로 동정하였다. 각 균주의 chromosomal DNA는 균체를 saline solution $(0.8 \% \mathrm{NaCl}$, $0.0125 \%$ tween 20)에 현탁 후 원심분리를 통하여 균사체를 획득한 다음, 얻어진 균사체에 lysis buffer(0.05M EDTA $(\mathrm{pH} 8.0), 0.3 \% \mathrm{SDS})$ 를 넣고 10 분간 방치하였다. 상등액을 취하여 멸균된 glass bead를 이용하여 균사체를 파쇄한 다 음, 원심분리(14,000 rpm, 3분)하고, 상등액을 취하여 동일 부피의 isoprophanol을 가하여 genomic DNA를 침전시켰다. 원심분리에 의해 얻어진 genomic DNA는 $70 \%$ ethanol로 세척하고, 얻어진 genomic DNA에 미량의 멸균수를 첨가한 다음 $60^{\circ} \mathrm{C}$ 에서 1 시간 처리 후 $\mathrm{PCR}$ 에 사용하였다. $\mathrm{PCR}$ 을 위해서 ITS-5.8S rDNA sequencing에 사용하는 universal primer인 ITS1(5'-TCCGTAGGTGAA CCTGCGG-3')와 ITS4(5'-TCCTCCGCTTATTGATATGC-3') primer를 사용 하여 수행하였다. 증폭된 정제된 PCR 산물은 ABI PRISM BigDye $^{\mathrm{TM}}$ Terminator Cycle Sequencing kits(Applied Biosystems Co., Foster City, CA, USA)를 사용하여 ABI PRISM 3730XL Analyzer(96 capillary type)를 통해 염기서 열을 분석하였으며, 그 결과는 BLASTN 프로그램을 이용 하여 GENEBANK의 ribosomal DNA sequence와 비교하였 고, sequence의 상동성은 Clustal X와 Mega 2 program을 이용하여 비교 분석하였다.

\section{부패 진균 선발}

생강의 부패에 관여하는 진균을 선발하기 위하여 선정된 우점 진균 10종을 Potato Dextrose Broth(PDB, Merck, Darmstadt, Germany)에 접종하고 $35^{\circ} \mathrm{C}$ 에서 3 일간 배양하였 다. 각각의 배양액 $100 \mu \mathrm{L}$ 를 건강한 생강의 표면에 접종 한 후 $30^{\circ} \mathrm{C}$ 에서 저장하면서 생강 조직의 괴사를 발생시킨 진균을 생강 부패 유도 진균으로 선발하여 항진균 활성 평가를 위한 시험균으로 사용하였다. 


\section{항균활성 측정}

실험 재료는 항균력이 있다고 알려져 있으며 현재 한약 재로 사용 중이거나 식용이 가능한 가자(Terminariae Fructus), 감초(Glycyrrhizae Radix), 계피(Cinnamomi Cortex), 민들레 (Taraxacum Platycarpum), 복분자(Rubi Fructus), 소목 (Caesalpiniae Lignum), 육두구(Myristicae Semen), 정향 (Caryophylli Flos), 지유(Sanguisorbae Radix), 초두구 (Alpiniae Katsumadaii Semen), 황금(Scutellariae Radix), 황 초(Astragalus membranaceus) 등 식물 추출물 12종을 선정 하였다. 선정된 식물 추출물은 한국식물추출물 은행으로부 터 분양 받은 에탄올 추출물을 본 실험에 사용하였다. 항진 균 활성 평가는 CLSI 방법(20)에 제시된 방법을 참고하여 수행하였다. 부패한 생강으로부터 분리된 Fusarium oxysporum을 PDA에 접종하여 $35^{\circ} \mathrm{C}$ 에서 3 일간 배양한 후 균체에 $0.85 \%$ 멸균 생리적 식염수 $1 \mathrm{~mL}$ 를 떨어뜨리고 피펫 으로 균체와 잘 혼합하였다, 그 위에 Tween 20 을 한 방울 떨어뜨린 후 혼합한 균액을 $1.5 \mathrm{~mL}$ 멸균 튜브에 담고 15 분 간 방치하였다. 상층액을 취하여 15 초간 vortexing 한 다음 $530 \mathrm{~nm}$ 에서 흡광도가 0.15-0.17가 되도록 0.85\% saline으로 조정하여 균수가 $6 \log \mathrm{CFU} / \mathrm{g}$ 수준이 되도록 하였다. 멸균 한 면봉에 시험액을 묻힌 후 Muller-Hinton agar(MHA, Hanil-KOMED, Seongnam, Korea) 표면에 고르게 도말하고, 5 분간 방치하여 표면이 마르게 하였다. 멸균된 paper $\operatorname{disc}(8$ $\mathrm{mm}$ )에 $\mathrm{DMSO}$ 에 용해시킨 12 종의 추출물은 $50 \%$ dimethyl sulfoxide(DMSO, Sigma-Aldrich Co., St. Louis, MO, USA) 로 $20 \mathrm{\mu g} / \mathrm{disc}$ 농도가 되도록 점적하여 흡수시킨 다음, $35^{\circ} \mathrm{C}$ 에서 3일간 배양하여 clear zone 생성 유무로 항균활성을 측정하였다.

최소저해농도(minimum inhibitory Concentration: $\mathrm{MIC}$ ) 측정

Paper disc assay를 통한 항진균 활성을 보인 식물 추출물 3종(계피, 민들레, 정향)을 대상으로 선발 곰팡이에 대하여 최소억제농도를 측정하였다. 항균활성 평가와 동일한 방법 으로 제조한 균액을 $\mathrm{MHA}$ agar에 도말한 후 5 분간 방치하여 표면이 마르게 한 후 멸균된 paper $\operatorname{disc}(6 \mathrm{~mm})$ 를 배지 위에 놓았다. 3종의 추출물은 $20,10,5,2.5,1.25 \mathrm{\mu g} / \mathrm{disc}$ 의 농도로 paper disc에 흡수시킨 후 $35^{\circ} \mathrm{C}$ 에서 3 일간 배양하였다. 배양 후 균 증식이 나타나지 않는 농도를 최소저해농도(MIC)로
결정하였다.

통계 분석

본 연구의 결과는 실험의 결과값을 평균표준편차로 나 타냈고, 각 실험군간의 비교 분석은 SPSS 12.0 프로그램을 이용하여 Duncan의 다중검정법(Duncan's multiple range test)으로 $\mathrm{p}<0.05$ 수준에서 유의성을 검증하였다.

\section{결과 및 고찰}

\section{진균류 오염도 평가}

생강에 포함된 다양한 종류의 곰팡이 균주를 분리하기 위하여 $10-12^{\circ} \mathrm{C}$ 에서 4 개월간 저장 한 후 부패가 일어 나지 않은 생강과 부패 현상을 보이는 생강을 수집하였다. 수집 된 생강 시료로부터 곰팡이를 분리하기 위하여 PDA에 도 말하여 $25^{\circ} \mathrm{C}$ 에서 배양한 결과, 저장 초기의 곰팡이와 효모 가 4.5, $3.0 \log \mathrm{CFU} / \mathrm{g}$ 이었던 것과 비교하여 부패가 나타나 지 않은 생강 시료의 곰팡이와 효모는 증가하지 않았으나 부패 현상을 보이는 생강 시료의 곰팡이와 효모는 증가한 것으로 나타났다(Table 1). 부패가 나타나지 않은 대조군의 경우 저장 후 곰팡이가 $4.1 \log \mathrm{CFU} / \mathrm{g}$ 로 저장 초기와 비교하 여 증가하지 않았고, 부패가 나타난 생강 시료의 곰팡이수 는 각각 5.2, $6.4 \log \mathrm{CFU} / \mathrm{g}$ 으로서, 초기 곰팡이 수와 비교하 여 약 1-2 $\log \mathrm{CFU} / \mathrm{g}$ 증가하였다. 효모의 경우에도 곰팡이와 비슷한 경향으로 대조군이 $3.5 \log \mathrm{CFU} / \mathrm{g}$ 인 반면, 부패한 생강의 효모는 5.0, $6.2 \log \mathrm{CFU} / \mathrm{g}$ 으로 나타났다. 이와 같은 결과는 $10^{\circ} \mathrm{C}$ 에서 70 일간 저장 한 생강 시료에서 곰팡이 증가가 나타나지 않았다는 Mishra 등(21)의 연구와 유사한 경향을 보였다. 본 연구 결과에서 부패하지 않은 생강 시료 와 부패한 생강 시료의 곰팡이수는 약 $1.5-2 \log \mathrm{CFU} / \mathrm{g}$ 차이 가 있는 것으로 나타났고 저온에서 장기간 저장 시 부패 현상에 관여하는 병원균을 분리하기 위하여 부패 현상이 없는 생강과 부패한 생강으로부터 형태학적 차이를 보이는 곰팡이를 분리하여 동정하였다.

\section{곰팡이 분리 및 동정}

생강 저장 시 우점하는 곰팡이와 부패에 직접적으로 관 여하는 곰팡이를 확인하고 선발하기 위하여 건강한 생강과

Table 1. The level of fungi on non-spoilage and spoilage ginger after storage for 120 days

\begin{tabular}{ccccc}
\hline & \multicolumn{4}{c}{ Storage day } \\
\cline { 2 - 5 } & 0 day & Non-spoilage ginger & Spoilage-ginger I & Spoilage-ginger II \\
\cline { 2 - 5 } & Fresh ginger & $4.1 \pm 0.14^{\mathrm{a}}$ & $5.2 \pm 0.02^{\mathrm{b}}$ & $6.4 \pm 0.09^{\mathrm{c}}$ \\
Mold & $4.5 \pm 0.25^{\text {abl }}$ & $3.5 \pm 0.49^{\mathrm{ab}}$ & $5.0 \pm 0.02^{\mathrm{b}}$ & $6.2 \pm 0.02^{\mathrm{c}}$ \\
\hline
\end{tabular}

${ }^{11}$ Means with different letters within a row are significantly different $(\mathrm{p}<0.05)$ by Duncan's multiple range test. 

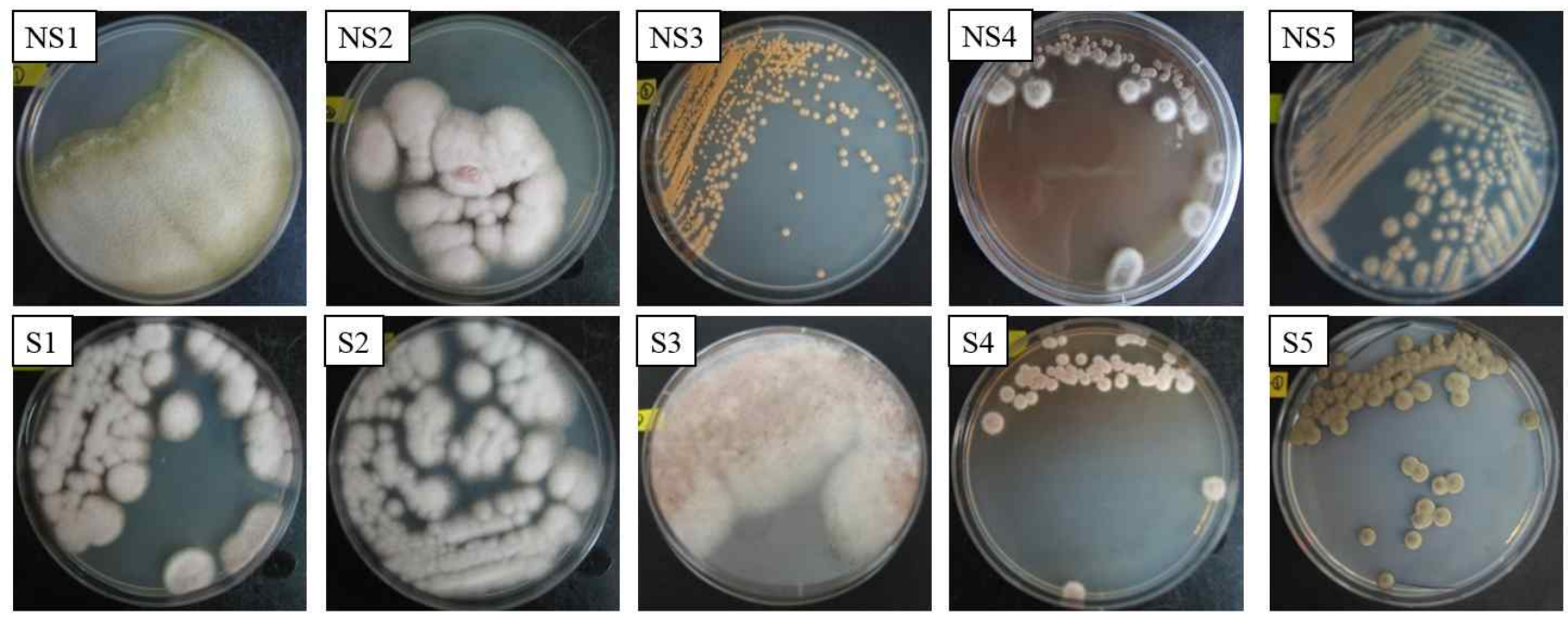

Fig. 1. Diversity of the fungal colonies from non-spoilage and spoilage ginger after storage for 120 days.

NS, non spoilage ginger; $S$, spoilage ginger.

부패한 생강 시료로부터 확인된 곰팡이를 PDA에 순수 분 리한 후 형태학적, 배양학적 특징이 구분되는 10 종의 곰팡 이를 선정하였다(Fig. 1). 분리된 각각의 곰팡이를 ITS-5.8S rDNA sequencing를 이용하여 분석한 후 ITS 영역의 염기서 열을 NCBI의 GenBank에 수록된 DNA 염기서열 database에 검색한 결과, 저장 후 부패가 발생하지 않은 생강으로부터 분리된 NS1, NS2, NS3, NS4는 phylogenetic tree 상에서 97\% 이상의 매우 높은 상동성을 나타내어 Hypocrea virescentiflava, Fusarium oxysporum, Acremonium strictum 에 속하는 균주임이 확인되었다. 반면 부패한 생강으로부 터 분리된 곰팡이의 ITS 염기서열은 $\mathrm{S} 1, \mathrm{~S} 2$ 가 F. oxysporum 과 70\%의 상동성을 나타냈고 S4는 Fusarium solani와 $92 \%$ 의 상동성을 S5는 Cadophora fastigiata의 염기서열과 $97 \%$ 의 높은 상동성을 나타내었다(Fig. 2). 생강의 뿌리 썩음병 을 일으키는 주된 원인균은 Pythium myriotylum이지만 $F$. solani와 F. oxysporum 역시 생강의 뿌리썩음병과 시들음병 에 직접적으로 관여하는 병원균으로 알려져 있다. 특히 $F$. oxysporum은 미국(22), 인도(23), 호주(24) 등과 같은 생강을 생산하는 많은 국가에서 뿌리썩음병을 일으키는 주된 병원 균으로 보고 되어있고, 토양에 다수 존재하고 있기 때문에 수확 후 가공 처리에 의해 발생되는 표면 상처 부위를 통해 토양 내 F. oxysporum가 유입되고 이로 인하여 표면이 괴사 되는 현상이 나타난다고 알려져 있다. 일반적으로 $P$. myriotylum은 $30^{\circ} \mathrm{C}$ 이상의 환경에서 부패병을 촉진한다고 알려진 반면(25) F. oxysporum은 $16^{\circ} \mathrm{C}$ 의 저온 환경에서도 부패병을 일으킬 수 있다고 보고되어 있고(26), 또한 Fusarium spp.의 경우 병원성보다는 부생성이 강한 진균으 로 부패가 어느 정도 진행된 작물로부터 쉽게 분리 된다고 보고되었다(27). 따라서 본 연구에서 확인된 결과와 마찬가
지로 장기간 동안 저온에서 저장된 생강의 부패에는 $F$. oxysporump 이 우선적으로 작용하는 것으로 판단된다. 본 연 구에서 생강의 병원성 검정 결과, 부패한 생강으로부터 분 리된 F. oxysporum 접종 시 5일 후 균사가 하얗게 자라났고 이들 균사와 포자는 주변으로 점차 번지면서 급속히 확산되 었다. 이는 $\mathrm{Li}$ 등(28)이 보고한 생강에 발생하는 마른썩음병 의 병징과 일치하였으므로 부패한 생강으로부터 분리된 F. oxysporum을 항진균 활성 평가를 위한 최종 시험균으로 선정하였다.

Table 2. Antifungal activities of natural plant extracts against Fusarium oxysporum isolated from stored ginger for 120 days by disc diffusion assay

\begin{tabular}{lc}
\hline \multicolumn{1}{c}{ Natural plant extract ${ }^{1)}$} & Clear zone (mm) \\
\hline Cinnamomi Cortex & $22.0^{2}$ \\
Taraxacum Platycarpum & 15.0 \\
Caryophylli Flos & 14.0 \\
Alpiniae Katsumadaii Semen & 11.8 \\
Sanguisorbae Radix & 10.9 \\
Scutellariae Radix & 10.9 \\
Myristicae Semen & 10.8 \\
Terminariae Fructus & 10.7 \\
Rubi Fructus & 10.3 \\
Glycyrrhizae Radix & 8.0 \\
Caesalpiniae Lignum & 8.0 \\
Astragalus membranaceus & 8.0 \\
\hline
\end{tabular}

${ }^{1)}$ Treated sample (medical herb extract) concentration: $20 \mu \mathrm{g} /$ disc.

${ }^{2}$ Clear zone size measured the diameter of the zone of inhibition including the diameter of the disc $(8 \mathrm{~mm})$. 

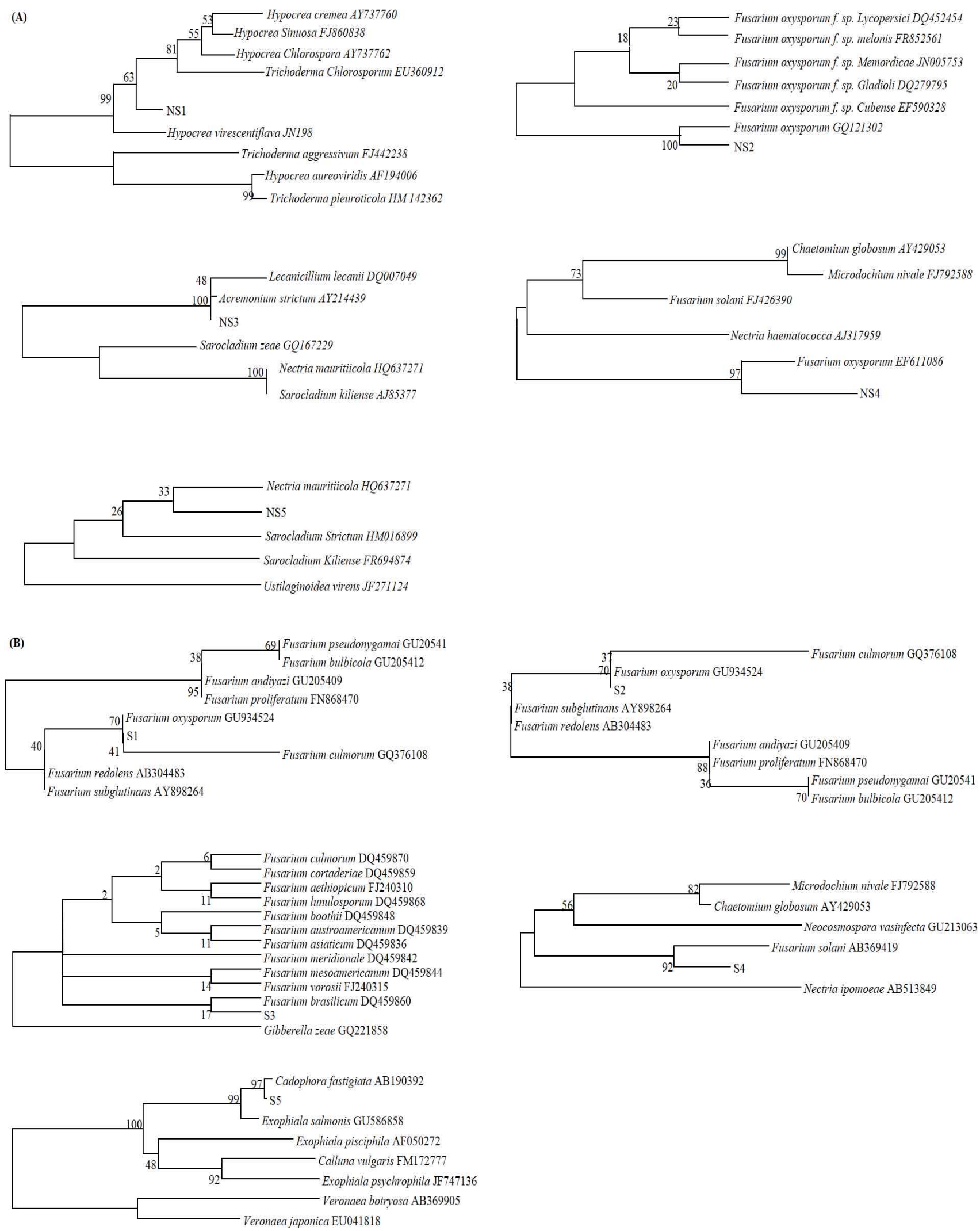

Fig. 2. Phylogenetic comparison of the ITS-5.8S rDNA region sequence of the this isolates with closely related strains and other species of dominant fungus from non spoilage ginger (A) and spoilage ginger (B) from GenBank.

The tree was constructed based on the neighbor-joining analysis and confidence intervals in tree topology were estimated by bootstrap analysis with 1,000 replicates. 

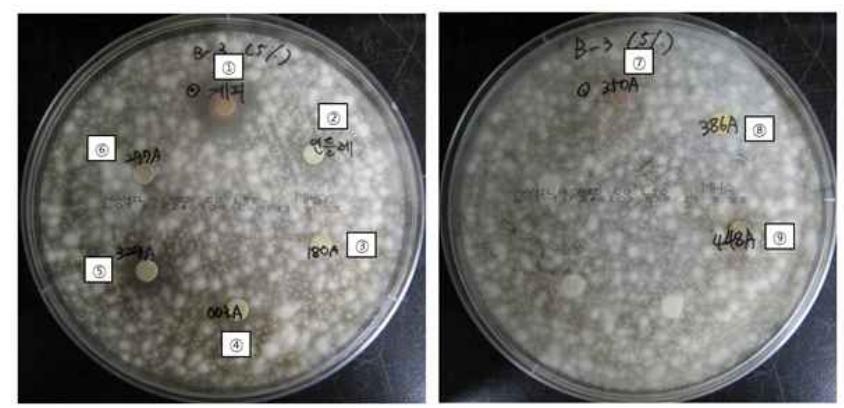

Fig. 3. Antifungal activity of natural plant extracts based on disc diffusion assay against Fusarium oxysproum isolated from stored ginger for 120 days.

Symbols; No.1, Cinnamomum cassia; No.2, Taraxacum Platycarpum, No.3, Rubus coreanus Miquel, No.4, Terminalia chebula Retzius, No.5, Eugenia caryophyllata; No.6, Myristica fragrans, No.7, Sanguisorba Officinalis, No.8, Apinia katsumadai, №.9, Scutellaria baicalensis.

\section{식물 유래 추출물의 항진균 활성 평가}

부패 생강 분리주인 F. oxysporum 에 대한 식물 추출물 12 종의 항진균 활성 탐색은 disc diffusion assay를 통해 측정 하였다(Table 2, Fig. 3). 그 결과, 계피, 민들레, 정향, 초두구, 지유, 황금, 육두구, 가자, 복분자등이 F. oxysporum에 대해 항균활성을 나타냄을 확인하였다. 그 중 계피의 clear zone 이 $22 \mathrm{~mm}$ 로 가장 우수한 항진균 활성을 나타냈고, 다음으 로 민들레가 $15 \mathrm{~mm}$, 정향이 $14 \mathrm{~mm}$ 로 우수한 항균 활성을 나타냈다. 그 외 초두구, 지유, 황금, 육두구, 가자, 복분자의 clear zone은 10.3-11.8 mm로 F. oxysporum에 항진균 활성을 보였다. Jeong 등(29)의 연구에 따르면 계피 추출물은 미생 물의 증식 억제 기능을 가지며, 특히 곰팡이류의 증식을 효과적으로 억제한다고 보고하였으며 이는 계피의 구성요 소 중 eugenol과 cinnamaldehyde가 높은 항균력을 함유하고 있기 때문이라고 보고하였다. 계피의 주요 성분 중 하나인 cinnamaldehyde는 항진균, 항균 특성 때문에 식품, 곡물, 식물의 post-harvest 관리 분야에서 많이 이루어지고 있고 특히 Botryodiplodia theobromae의 성장을 현저하게 감소시 킴으로써 과일의 저장 중 부패를 감소시킨다고 보고된 바 있으며 또한 채소의 저장 중 부패를 야기하는 Erwinia cartovora 등의 부패균에도 효과가 있음이 밝혀진 바 있다. 이와 함께 국화과 역시 항균성이 높다고 보고되어 있으며, 특히 민들레 추출물은 높은 flavonoid와 phenolic acid를 함 유하고 있고 이와 같은 성분이 미생물의 세포막에 침투하는 성질을 가지며 이는 세균의 세포막을 파괴시킴으로써 세포 성분이 유출되어 항균 활성을 나타낸다고 보고되고 있다 (30,31). 그러나 민들레 추출물의 F. oxysporum에 대한 항균 활성결과는 아직 보고된 바는 없으나 민들레 추출물이 가지 고 있는 phenolic acid와 flavonoid 성분이 곰팡이의 세포막 손상과 성분 유출에 의한 항진균 활성에도 관여할 수 있는 것으로 사료된다. 정향은 향신료의 일종으로서 주성분인 eugenol은 곰팡이의 aflatoxin을 억제하고(32) Listeria monocytogenes와 Aeromonas hydrophila의 증식을 억제한다 고 보고되었다(33). 그 외 약용식물인 지유와 황금 추출물 역시 Bacillus cereus, Bacillus subtilis, Staphylococcus aureus, Vibrio parahaemolyticus, E. coli와 Salmonella typhymurium 에 대하여 생육억제 효과를 보인다고 보고되었다 $(34,35)$. 지금까지 계피, 민들레, 정향 등 약용식물 추출물의 항진균 효과에 대한 연구는 미미한 편이므로 본 연구 결과를 통해, 생강의 저온 저장시 나타나는 시들음 또는 뿌리썩음병을 억제할 수 있는 천연 항균 물질로서 이용 가능성이 높다고 사료된다.

식물 추출물의 생강 부패 분리 곰팡이에 대한 최소억제농도

12 종의 추출물의 항진균활성을 평가한 결과 계피, 민들 레, 정향 추출물의 항균활성이 높은 것으로 확인되었고 이 들 3종의 식물 추출물의 항진균 효과를 보다 정확하게 평가 하기 위하여 최소억제농도 확인을 통하여 항진균활성을 정량적으로 분석하였다(Table 3). F. oxysporum에 대하여 민들레 추출물이 $2.5 \mathrm{\mu g} / \mathrm{disc}$ 로 가장 낮은 농도에서 곰팡이 분리주의 생장을 억제하였고, 계피와 정향은 $10 \mu \mathrm{g} / \mathrm{disc}$ 의 농도에서 억제활성이 있음이 확인되어 민들레에 의한 $F$. oxysporum 억제 효과가 가장 우수한 것으로 나타났다. 민들 레 추출물은 Bacillus subtilis, Pseudomonas flourescens, $L$. monocytogenes와 S. aureus의 성장을 억제한다는 보고 $(36,37)$ 가 있고 특히 $2 \mathrm{mg} / \mathrm{mL}$ 농도에서 L monocytogenes와 S. aureus를 $95 \%$ 이상 억제하는 효과가 있다고 보고하였으 나 민들레 추출물에 의한 항진균 효과에 대한 보고는 없었 다. 따라서 본 연구 결과를 통해 민들레 추출물은 식물 병원 균인 F. oxysporum에 대한 항진균 활성이 우수하다고 할 수 있으며 F. oxysporum에 의해 발생되는 시들음병과 뿌리 썩음병의 발생을 억제시킬 수 있는 천연 항균제로서의 적용 가능성을 기대할 수 있다고 판단된다. 계피 또한 Aspergillus niger에 대해 우수한 항진균 활성을 보여 천연 방부제로서 활용할 수 있다고 보고되었고(19) Mvuemba 등(38)의 연구 에서는 $150 \mathrm{mg} / \mathrm{mL}$ 의 농도에서 $A$ niger와 Fusarium sambucinum등의 mycelia 형성을 억제하였다는 보고하였는 데 본 연구에서는 $500 \mu \mathrm{g} / \mathrm{mL}$ 수준에서 F. oxysproum을 억제 할 수 있는 것으로 나타났다. 이는 사용한 균주의 차이로

Table 3. Minimal inhibitory concentrations of 3 selected natural plant extracts against Fusarium oxysporum isolated from stored ginger for 120 days by disc diffusion assay

\begin{tabular}{lc}
\hline \multicolumn{1}{c}{ Natural plant extract ${ }^{1)}$} & MIC $(\mu \mathrm{g} / \mathrm{disc})$ \\
\hline Cinnamomi Cortex & $10^{2)}$ \\
Taraxacum Platycarpum & 2.5 \\
Caryophylli Flos & 10 \\
\hline
\end{tabular}

${ }^{1)}$ Treated sample (medical herb extract) concentration: $20 \mu \mathrm{g} / \mathrm{disc}$.

${ }^{2)}$ Clear zone size measured the diameter of the zone of inhibition including the diameter of the disc $(8 \mathrm{~mm})$. 
생각되며 이와 함께 항진균성 물질을 추출할 때 용매 농도 및 용매의 종류에 따라 항진균력에 차이가 있기 때문이라고 사료된다. 본 연구에서 정향 추출물 또한 $F$. oxysporum에 대하여 우수한 항균 효과를 보였는데, 이는 Sharma 등(39) 의 연구 결과에서 정향 추출물 $12.5 \mathrm{mg} / \mathrm{mL}$ 에서 $F$. oxysporum의 성장 억제에 높은 활성을 보였다는 보고와 Sukatta(40)의 연구에서 포도의 부패를 일으키는 Rhizopus stolonifera에 대해 정향 추출물이 항균 활성을 보였다는 결과와 유사하게 나타났다. 이와 같은 결과를 통하여 민들 레, 계피, 정향 추출물이 식물부패 원인균인 F. oxysporum에 대해 우수한 항균활성을 나타내 항균제제로 활용할 가능성 이 있다고 판단된다.

\section{요 약}

본 연구에서는 생강의 저온 저장시 시들음병 또는 뿌리 썩음병을 발생시키는 병원균을 확인하고, 병원균의 성장을 억제할 수 있는 새로운 천연 항진균 물질을 찾기 위한 목적 으로 식물 추출물을 이용하여 항진균 활성을 조사하였다. 부패한 생강으로부터 분리된 곰팡이는 총 4종으로 $F$. oxysporum, F. bracilicum F. solani, C. fastigiata으로 동정되 었고 이중 생강의 부패 현상에 영향을 주는 곰팡이는 $F$. oxysporum으로 확인되었다. 분리된 F. oxysporum에 대하여 총 12 종의 식물 추출물을 이용하여 항진균 활성을 측정한 결과 계피, 민들레, 정향 추출물이 부패 곰팡이인 $F$. oxysporum에 대한 항진균 활성이 높게 나타났다. 이들 추출 물의 최소저해농도를 측정한 결과, 민들레 추출물은 2.5 $\mu \mathrm{g} / \mathrm{disc}$, 계피와 정향 추출물이 각각 $10 \mu \mathrm{g} / \mathrm{disc}$ 로서 민들레 추출물이 가장 낮은 농도에서 효과적으로 F. oxysporum의 성장을 억제하였다. 상기의 결과를 종합해볼 때 민들레, 계피, 정향 추출물이 F. oxysporum에 대하여 항진균 활성이 우수한 것으로 나타나 저장 중 생강의 부패 현상을 억제하기 위한 항진균 제제의 소재로써 활용 할 수 있다고 판단된다.

\section{감사의 글}

본 연구는 농림식품식품부의 재원으로 농림수산식품기 술기획평가원의 고부가가치식품기술개발사업과 한국식 품연구원의 연구비 지원에 의해 이루어진 것이며 이에 감사 드립니다.

\section{References}

1. Cornell DW (1969) The pungent principle of ginger and their importance in certain ginger products. Food Technol Austral, 21, 570-575

2. Lee HS, Kwon KH, Kim BS, Kim JH, Cha HS, Chung $\mathrm{KH}$ (2010) Optimization of the molecular press dehydration method for ginger using response surface methodology. Korean J Food Sci Technol, 42, 398-406

3. Lee WH, Lee DK (1998) Ecology of rhizome rot incidence of ginger and relation of soil texture, chemistry and biology. Korean J Environ Agric, 17, 1-4

4. Kim CH, Yang SS, Hahn KD (1998) Effect of soil disinfection, fungicide application, and narrow ridge cultivation on development of ginger rhizome rot caused by Pythium myriotylum in fields. Korean J Plant Pathol, 14, 253-259

5. Peterson JL, Pound GS (1960) Studies on resistance in radish to Fusarium oxysporum f. sp. conglutinans. Phytopathology, 50, 807-816

6. Desjardins AE, Hohn TM (1997) Mycotoxins in plant pathogenesis. Mol Plant-Microbe Interact, 10, 147-152

7. Van Asch MAJ, Rijkenberg FHF, Coutinho TA (1992) Phytotoxicity of fumonisin B1, moniliformin, and T-2 toxin in corn callus cultures. Phytopathology, 82, 1330-1332

8. Kim HS, Choi JH, Lee HJ, Jeong MC, Kim BS, Kim DM (2010) Quality characteristics of treated with mild heat and minced ginger during storage. Korea J Food Preserv, 17, 784-792

9. Choi YH, Lee SB, Kim MS (1997) Improvement of quality and prolongation in chopped ginger storage. Korean J Agric Chem Biotechnol, 40, 123-127

10. Lee MH, Lee YK, Kim KT (2010) Quality characteristics of minced ginger during storage. Korean J Food Preserv, 17, 23-29

11. Chung HS, Lee HJ, Moon KD (2010) Effects of ethylene absorbent on quality changes of fresh ginger rhizomes during modified atmosphere storage. Korean J Hortic Sci Technol, 28, 82-88

12. Lee HO, Lee YJ, Kim JY, Kwon KH, Kim BS (2017) Extension of ginger shelf-life using a forced evaporation humidifier. Hortic Sci Technol, 35, 555-567

13. Paull RE, Chen NJ, Goo TTC (1988) Compositional changes in ginger rhizomes during storage. $\mathrm{J}$ Am Soc Hortic Sci, 113, 584-588

14. Paull RE, Chen NJ, Goo TTC (1988) Control of weight loss and spouting of ginger rhizome in storage. Hortscience, 23, 734-736

15. Choi GJ, Kim JC, Jang KS, Lim HK, Park IK, Shin SC, Cho KY (2006) In vivo antifungal activities of 67 plant fruit extracts against six plant pathogenic fungi. 
J Microbiol Biotechnol, 16, 491-495

16. Ahn SM, Lee DS, Kim MS, Choi SJ, Choi CS, Lee JB, Jang HS, Sohn HY (2009) Bioactivity of the extract of Coptis chinensis: In-vitro antifungal activity against phytophthora capsica and growth-promotion effect in red-pepper. Kor J Microbiol Biotechnol, 37, 280-286

17. Lee JM, Hur SS (2014) Isolation and identification of antifungal compounds from Eugenia caryophyllata Extracts. J Korean Oil chem Soc, 31, 740-747

18. Kim BS, Jang HS, Choi CS, Kim JS, Kwon GS, Kwun IS, Son KH, Sohn HY (2008) Antifungal activity of Zanthoxylium schinifolium against Fusarium graminearum, a barley powdery mildew fungus. J Life Sci, 18, 974-979

19. Cho EM, Bae JT, Pyo HB, Lee GS (2008) Antimicrobial plant Extracts as an alternative of chemical preservative: Preservative efficacy of Terminalia chebula, Rhus japonica (gallut) and Cinnmomum cassia extract in the cosmetic formular. J Soc Cosmet Sci Korea, 34, 325-331

20. CLSI (2006) Performance standards for antimicrobial disk and dilution susceptibility tests for bacteria isolated from animals; Approved standard, $3^{\text {th }}$ ed, CLSI document M31-A3, Clinical and Laboratory Standards Institute, Wayne, PA, USA, p 13-24

21. Mishra BB, Gautam S, Sharma A (2004) Shelf life extension of fresh ginger (Zingiber officinale) by gamma irradiation. J food sci, 69, 274-279

22. Trujillo EE (1964) Fusarium yellows and rhizome rot of common ginger. Phytopathology, 53, 1370-1371

23. Dake GN, Edison S (1989) Association of pathogens with rhizome rot of ginger in Kerala. Indian Phytopathol, 42, 116-119

24. Stirling AM (2002) Erwinia chrysanthemi, the cause of soft rot in ginger (Zingiber officinale) in Australia. Australas Plant Pathol, 31, 419-420

25. McCarter SM, Littrell RH (1970) Comparative pathogenicity of Pythium aphanidermatum and Pythium myriotylum to twelve plant species and intraspecific variation in virulence. Phytopathology, 60, 264-268

26. Khaled H, Mejda DR, Hayfa JK, Mohamed EM (2006) Temperature Effect on mycelial growth and on disease incidence of Fusarium oxysporum f. sp. radicis-lycopersici. Plant Pathol J, 5, 233-238

27. Shin JH, Yun BD, Kim HJ, Kim SJ, Chung DY (2012) Soil environment and soil-borne plant pathogen causing root rot disease of ginseng. Korean J Soil Sci Fert, 45, 370-376

28. Li Y, Chi LD, Mao LG, Yan DD, Wu ZF, Ma TT, Guo MX, Wang QX, Ouyang CB, Cao AC (2014) First report of ginger rhizome rot caused by Fusarium oxysporum in China. Plant disease, 98, 282

29. Jeong ET, Park MY, Lee JG, Chang DS (1998) Antimicrobial activity and antimutagenesis of cinnamon (Cinnamomum cassia Blume) bark extract. J Food Hyg Saf, 13, 337-343

30. Yang L, Li HF, Diao HP, Tang XY, Peng TF, Sun TJ (2011) Total phenolic acid content, total flavonoid content and antioxidant activity of dandelion flowers. Food Sci, 32, 160-163

31. Xia DZ, Wu XQ, Shi JY, Yang Q, Zhang Y (2011) Phenolic compounds from the edible seeds extract of Chinese Mei (Prunus mume Sieb. Et Zucc) and their antimicrobial activity. LWT-Food Sci Technol, 44, 347-349

32. Karapinar M (1990) Inhibitory effects of anethole and eugenol on the growth and toxin production of Aspergillus parasiticus. Int J Food microbiol, 10, 193-197

33. Hao YY, Brackett RE, Doyle MP (1998) Inhibition of Listeria monocytogenes and Aeromonas hydrophila by plant extracts in refrigerated cooked beef. J Food Prot, 61, 307-312

34. Kil KJ, Doh ES, Chang JP, Lee SH, Yoo JH (2015) Antibacterial and antioxidant activities of bio-fermented Sanguisorbae radix extract. Korea J Herbol, 30, 29-35

35. Lee CK, Seo JJ (2005) Antimicrobial activity of Whangkumtang extract and Scutellariae radix extract on the food-borne pathogens. J Korean Soc Food Sci Nutr, 34, 1606-1610

36. Lee BW, Shin DH (1991) Screening of natural antimicrobial plant extract on food spoilage microorganism. Korean J Food Sci Technol, 23, 200-201

37. Kim KH (1999) Isolation and identification of antimicrobial compounds from dandelion and plantains and their effects when added to processed foodstuffs. $\mathrm{Ph}$ D Thesis, Sookmyung Women's University, Korea, p 43-45

38. Mvuemba HN, Green SE, Tsomo A, Avis TJ (2009) Antimicrobial efficacy of cinnamon, ginger, horseradish and nutmeg extracts against spoilage pathogens. Phytoprotection, 90, 65-70

39. Sharma A, Rajendran S, Srivastava A, Sharma S, Kundu B (2017) Antifungal activities of selected essential oils against Fusarium oxysporum f. sp. lycopersici 1322, with emphasis on Syzygium aromaticum essential oil. J Biosci Bioeng, 123, 308-313

40. Udomlak S, Vichai H, Walairut C, Uraiwan D, Panuwat $S$ (2008) Antifungal activity of clove and cinnamon oil and their synergistic against postharvest decay fungi of grape in vitro. Nat Sci, 42, 169-174 